\title{
Medication adherence: a review of pharmacy education, research, practice and policy in Finland
}

\author{
J. Simon BELL, Hannes ENLUND, Kirsti VAINIO. \\ Received (first version): 21-Jun-2010 Accepted: 17-Aug-2010
}

\begin{abstract}
${ }^{*}$
Aims: To describe pharmacy education, research, practice and policy related to medication adherence in Finland since the year 2000.

Methods: The three universities that provide pharmacy education (Åbo Akademi, University of Eastern Finland, and University of Helsinki) completed a structured pro-forma questionnaire regarding education related to medication adherence. A MEDLINE and EMBASE literature search was performed to identify English language peer-reviewed research that reported medication compliance, adherence or persistence. The Ministry of Social Affairs and Health was invited to nominate policies and documents related to medication adherence. A narrative review of medication counselling practices and professional service delivery through Finnish community pharmacies was undertaken.

Results: Medication adherence was a theme integrated into obligatory and elective courses for bachelors and masters degree students. The literature search identified 33 English language peer-reviewed research articles reporting medication compliance, adherence or persistence published since the year 2000. Policy documents of the Ministry of Social Affairs and Health recognise that poor medication adherence may lead to suboptimal treatment outcomes, and encourage patient participation in treatment decision making. Adherence practice in Finnish pharmacies has been strongly linked to the development of medication counselling services.

Conclusions: Adherence research and education has focused on understanding and addressing the
\end{abstract}

\footnotetext{
*J. Simon BELL. Kuopio Research Centre of Geriatric Care, University of Eastern Finland. Kuopio (Finland); and Clinical Pharmacology and Geriatric Pharmacotherapy Unit, School of Pharmacy, Faculty of Health Sciences, University of Eastern Finland. Kuopio (Finland). Hannes ENLUND. Social Pharmacy, School of Pharmacy, Faculty of Health Sciences, University of Eastern Finland. Kuopio (Finland); and Department of Pharmacy Practice, Kuwait University. Kuwait City (Kuwait).

Kirsti VAINIO. Social Pharmacy, School of Pharmacy, Faculty of Health Sciences, University of Eastern Finland. Kuopio (Finland).
}

Series editors:

Marie P. SCHNEIDER. PhD. Researcher and lecturer in Pharmacy Practice. Community Pharmacy, Dpt of ambulatory care and community medicine, University Hospital, Lausanne (Switzerland).

Parisa ASLANI. PhD. Senior Lecturer in Pharmacy

Practice. Faculty of Pharmacy, University of Sydney (Australia). contextual factors that contribute to medication nonadherence. Adherence practice in community pharmacies has tended to focus on medication counselling and programs specific to particular disease states. Medication adherence is a topic that is integrated into courses for bachelor's and master's level pharmacy students in Finland.

Keywords: Medication Adherence. Pharmacists. Education, Pharmacy. Finland.

\section{CUMPLIMIENTO DE MEDICACIÓN: REVISIÓN DE EDUCACIÓN FARMACÉUTICA, INVESTIGACIÓN PRÁCTICA Y POLÍTICA EN FINLANDIA}

\section{RESUMEN}

Objetivos: Describir la educación farmacéutica, investigación, practica y política relacionadas con la adherencia a la medicación en Finlandia desde el año 2000.

Métodos: Las tres universidades que proporcionan formación en farmacia (Åbo Akademi, Universidad de Finlandia Este, y Universidad de Helsinki) completaron un cuestionario pro-forma estructurado en relación a la educación sobre cumplimento de la medicación. Se realizó una búsqueda de literatura en MEDLINE y EMBASE para identificar investigación revisada, en lengua inglesa, que comunicase cumplimiento, adherencia o persistencia. Se invitó al Ministerio de Asuntos Sociales y Salud para que relatase las políticas y documentos relacionados con el cumplimiento de la medicación, Se realizó una revisión narrativa de las prácticas de aconsejamiento de medicación y servicios profesionales a través de las farmacias comunitarias finlandesas.

Resultados: La adherencia a la medicación fue una materia integrada en los cursos obligatorios y optativos de los estudiantes de grados de licenciado y máster. La búsqueda de literatura identificó 33 artículos revisados de investigación en lengua inglesa que comunicaban cumplimiento de medicación, adherencia o persistencia publicados desde el año 2000. Los documentos políticos del Ministerio de Asuntos Sociales y Salud reconocían que la baja adherencia a la medicación podría conducir a resultados sub-óptimos del tratamiento y animaban a la participación de los pacientes en la toma de decisiones. Las prácticas de adherencia en farmacias comunitarias finlandesas ha estado fuertemente vinculada al desarrollo de servicios de aconsejamiento. 
Conclusiones: La investigación y la educación sobre adherencia se han centrado en entender y afrontar los factores de contexto que contribuyen al incumplimiento de medicación. Las prácticas de adherencia en farmacias comunitarias han tendido a centrarse en aconsejamiento de medicación y programas específicos para determinadas enfermedades. La adherencia a la medicación es una materia que está integrada en los cursos de licenciatura y máster de los estudiantes de farmacia en Finlandia.

Palabras clave: Adherencia a la medicación. Farmacéuticos. Educación farmacéutica. Finlandia.

\section{INTRODUCTION}

Medication non-adherence has been recognised as a preventable cause of treatment failure in Finland and internationally. ${ }^{1-3}$ Adherence to beneficial medication therapy has been associated with lower mortality, while adherence to harmful medication therapy has been associated with increased mortality. ${ }^{4}$

Medication adherence has been defined as the extent to which a patient's behaviour matches agreed recommendations from the prescriber. $^{5}$ Patient compliance has been defined as the extent to which a patient's behaviour matches the prescriber's recommendations. ${ }^{5}$ Medication adherence emphasises the need for agreement and, therefore, has largely replaced the term patient compliance (the latter term has been judged paternalistic by some authors). ${ }^{6}$ Medication persistence refers to the act of continuing the treatment for the prescribed duration. ${ }^{7}$ it is often defined as the time from treatment initiation to discontinuation. However, there are inconsistencies in how these concepts have been operationalised and a variety of methods by which they are measured. $^{6-10}$ Not all data sources permit researchers to assess agreement in medication taking (for example, health registers and pharmacy administrative databases).

There has been a long tradition of conducting research into medication adherence in Finland since the 1970 s and 1980s. ${ }^{11-16}$ All health professionals in Finland have a professional obligation to ensure that patients are provided with information to facilitate the rational use of medications. In contrast to some other countries, medication adherence in Finland has historically been studied and taught from a health-system and patient perspective. The philosophy behind this approach has been the desire to better understand the contextual factors that contribute to medication non-adherence. Traditional methods of estimating medication adherence (including use of prescription claims records, pharmacy dispensing data, validated survey instruments or electronic pill counters) may themselves provide little insight into the reasons for non-adherence. ${ }^{17}$ Consistent with the health-system perspective, medication adherence research has been conducted by pharmacy, medical, nursing and dental researchers. An important development for adherence-related practice and research in Finland was the establishment of the Finnish National Prescription Register in 1993 (with complete data available since 1994). ${ }^{18}$ Register-based epidemiology is a form of epidemiological research that involves using data from health registers. ${ }^{19}$ The Finnish National Prescription Register includes patient level data on reimbursed medications for all 5.3 million Finnish residents. Data from a health register can be linked with data from another register (a 'register linkage study') or be supplemented by survey or clinical data. This has provided the opportunity to quantitatively investigate factors associated with adherence and persistence at a national population level. However, in comparison to several other countries, relatively little research has focused on interventions to improve adherence. ${ }^{20-23}$

The objective of this review was to describe pharmacy education, research, practice and policy related to medication adherence in Finland since the year 2000. This review forms part of an international series of articles describing pharmacy education, research, practice and policy in relation to adherence in different countries.

\section{METHODS}

Pharmacy education related to adherence

University lecturers or instructors at each of the three institutions that offer bachelor's and/or master's level pharmacy education in Finland were contacted and asked to complete a structured proforma questionnaire regarding the content and duration of the education they provided in relation to adherence. These institutions were the (1) Åbo Akademi, (2) University of Eastern Finland (University of Kuopio prior to 2010), and (3) University of Helsinki. The University of Eastern Finland and University of Helsinki provide both bachelor's and master's level pharmacy education in Finnish. The Åbo Akademi provides bachelor's level pharmacy education in Swedish.

\section{Adherence research}

For the purpose of this review, adherence research was deemed to include that related to compliance, adherence, or persistence with prescription or nonprescription medications. Due to the fact that adherence-related research in Finland has been characterised by a health-system approach and multidisciplinary collaboration, the review of published research was not limited to that conducted by pharmacists.

MEDLINE was searched using the Medical Subject Headings (MeSH) terms "patient education", "medication adherence", "patient compliance", and "drug information services" combined with "Finland". A title search was performed using the terms "compliance", "adherence" and "persistence" combined with "Finland". An author search was conducted using names of key medical and 
pharmacy researchers in Finland. EMBASE was searched using the EMTREE term "patient compliance" combined with "Finland". The reference lists of articles retrieved were screened to identify any additional articles meeting the review inclusion criteria. The inclusion criteria for adherence research were that a study 1) quantitatively or qualitatively reported an estimate of medication adherence, or factors associated with medication adherence, and 2) be published in an English language peer-reviewed journal. The search was limited to research published from 2000 until present. All study designs were considered for review. However, reports of pharmaceutical company sponsored randomised controlled trials (RCTs) investigating specific active ingredients were excluded (for example, RCT investigating use of orlistat in patients treated with clozapine or olanzapine). ${ }^{24}$ Reports of multicentre research studies in which Finnish researchers or hospitals were part of an international collaboration were also excluded (for example, multi-centre research into adherence with osteoporosis medications) ${ }^{25}$ Each identified article that met the review inclusion criteria was systematically reviewed according to the year of publication, study design, study sample, main outcome measures and main findings.

\section{Adherence policy}

The Finnish Ministry of Social Affairs and Health (MSAH) is the organ of government responsible for ensuring that there are sufficient social and health services. The MSAH was contacted and asked to nominate policies and documents relevant to medication adherence. This was because the MSAH is responsible for drafting legislation, designing health reforms, and implementing the government's health care program. ${ }^{26}$ These policies and documents were then qualitatively reviewed for content related to medication adherence.

Community pharmacy practice related to adherence

A narrative review of medication counselling practices and professional service delivery through Finnish community pharmacies was undertaken to supplement an earlier article on this topic. ${ }^{27}$ This method was selected because there is no professional pharmacy program specifically focused on improving or monitoring medication adherence in Finland. However, adherence practice in Finnish pharmacies has been strongly linked to the development of medication counselling services.

\section{RESULTS AND DISCUSSION}

\section{Pharmacy education related to adherence}

Pharmacy education in Finland has been undergoing reform so that it is consistent with the principles outlined in the Bologna Declaration, an agreement signed by 29 European countries in 1999 to create a common framework for higher education across Europe. ${ }^{28}$ The two pharmacy degree qualifications are the Bachelor of Science in Pharmacy (BSc. Pharm) and the Master of Science in Pharmacy (MSc. Pharm).
The Bachelor's degree involves three years of study and includes up to six months of practical training in a community pharmacy (with the option to spend three months working in a hospital). The six months practical training is divided into two three-month periods to ensure a close integration between university-based and practical training. ${ }^{28}$ An objective of the Bachelor's degree is to develop professional competencies required for work in community pharmacies. The curriculum is based on chemistry, pharmaceutics, and the biomedical and social sciences. ${ }^{27}$ Bachelor's graduates are called "farmaseutti" and $90 \%$ of those who do not continue studying for their Master's degree work in a community pharmacy after graduation. ${ }^{29,30}$ Graduates with a Bachelor's degree program are occasionally referred to as "prescriptionists." However, they commonly undertake roles performed by pharmacists in other countries. This can include taking responsibility for the operation of a main or subsidiary pharmacy when the owner is not present.

The Master's degree requires an additional two years of coursework and also involves completing a research project in a discipline of the student's choice. ${ }^{27}$ Pharmacists must be educated to at least the Master's level before they can apply to own a community pharmacy. Following graduation sixty percent of Master's degree graduates work in community pharmacies as salaried pharmacists or owners. ${ }^{29,30}$

Education is not as clinically oriented as in some other countries including the United States, United Kingdom and Australia. ${ }^{31-33}$ However, courses have been developed to be consistent with national and international professional guidelines. ${ }^{28}$ This includes Directives of the European Parliament and the Council of the European Union that relate to pharmacy education. ${ }^{34}$ Curriculum reform has also been guided by external and internal feedback and evaluation. ${ }^{35,36}$ The Bachelor's and Master's degrees do not include courses specific to medication adherence. However, medication adherence is a theme that has increasingly been integrated into Bachelor's and Master's level courses for pharmacy students. Medication adherence is a theme that is covered in many courses throughout the degrees (Table 1). Bachelor's and Master's level pharmacists can undertake an 18-month postgraduate training course to perform comprehensive medication reviews for people at high-risk of experiencing medication-related problems, including medication non-adherence. ${ }^{37}$

\section{Adherence research}

The systematic search of English language peerreviewed literature published from 2000 until present identified 33 Finnish papers that reported compliance, adherence or persistence with medications (Table 2). Thirteen papers focused on cardiovascular medications (including statins and antihypertensive medications) ${ }^{38-50}$, and 12 papers on medications for mental or neurological disorders (including antidepressants, antiepileptics, and medications for opioid dependence). ${ }^{51-62}$ The 
remaining papers investigated compliance or adherence in relation to medications for glaucoma ${ }^{63}$, diabetes $^{62,64-68}$, juvenile rheumatoid arthritis ${ }^{62,69}$, and asthma. ${ }^{21,62}$ Seven papers assessed compliance or adherence to health treatment regimens (including medication compliance and adherence) among children and adolescents. ${ }^{56,57,59,62,64,65,69}$

\section{Study designs and data sources}

Four papers used the National Prescription Register as the only data source. ${ }^{38-40,59}$ Two papers combined data from the National Prescription Register with data obtained from the National Hospital Discharge Register and/or Cause of Death Register. ${ }^{47,50}$ Seven papers combined medication data from the National Prescription Register and data from postal surveys concerning perceived support from physicians, nurses and parents, motivation, sense of coherence, threat to social well-being, fear of acute problems, and energy and will power. ${ }^{41,56,57,62,64,65,69}$ Six of these papers reported data from 1200 children and adolescents with epilepsy, juvenile rheumatoid arthritis, insulindependent diabetes mellitus or asthma. ${ }^{56,57,62,64,65,69}$ Three studies utilised qualitative interviews. ${ }^{48,60,63}$ Only one study was an intervention study conducted in community pharmacies. ${ }^{21}$

Three papers reported data from the same prospective cohort study (Vantaa Depression Study) ${ }^{53,54,58}$, and one study used data from the Drugs and Evidence-Based Medicine in the Elderly (DEBATE) RCT. ${ }^{42}$ One study was an observational study on compliance monitoring ${ }^{51}$, and another was a retrospective hospital medical record review study. ${ }^{52}$

Three papers reported data from a health examination and cross-sectional mail survey of general practice patients ${ }^{44-46}$, and one study was a cross-sectional mail survey of patients of nine community pharmacies. ${ }^{43}$ Two papers reported data from the same cross-sectional mail survey of people with insulin-treated diabetes. ${ }^{66,67}$ Two papers described prospective interview studies of patients with first onset psychosis and hospital outpatients receiving neuroleptic medications. ${ }^{55,61}$ Two further studies reported cross-sectional surveys of patients with diabetes ${ }^{68}$, and hypertension ${ }^{49}$, with the latter being for the purpose of developing a compliance scale.

\section{Measurement of adherence}

Studies that used the Finnish National Prescription Register or medical records defined adherence according to the proportion of days or time periods covered by dispensed medications. ${ }^{41,50,52,54,61}$ Persistence was defined according to the time from treatment initiation to discontinuation. ${ }^{38-40,47,59}$ Of those studies that used a patient self-completed survey to assess adherence none used a validated medication adherence specific scale, for example, the Morisky Scale ${ }^{70}$, or Medication Adherence Report Scale. ${ }^{71}$ Instead these studies used items including "I carry out my medical treatment according to the instructions given by my doctor or nurse" and "I do not carry out the medical treatment as instructed because the medicine causes side- effects" to define medication adherence as part of a patient's overall adherence to a health-care regimen. ${ }^{56,57,62,64,65,69}$ Other researchers determined patient self-reported medication non-adherence by asking questions including "did you take your medication less often than prescribed by your physician during the past year", "did you modify dosage instructions during the past year", "did you accomplish daily insulin injections as scheduled", or "did you have difficulty remembering to take your medications". 21,43-46,66-68 Four studies reported patient non-adherence categorised by physicians following a patient interview ${ }^{42,53,58,61}$, with one study comparing physician and patient assessments. ${ }^{61}$ One study described the development and validation of an instrument to measure adherence. ${ }^{49}$ Another study reported the use of an electronic adherence monitoring device that used mobile phone technology to record the time each dose was taken. ${ }^{51}$ Three studies qualitatively examined factors associated with medication adherence and did not provide a quantitative estimate of medication adherence. $^{48,60,63}$

\section{Professional background of researchers}

The first author was affiliated with a school of pharmacy in eight of the 33 research publications. ${ }^{21,43-46,51,59,60}$ Other publications were co-authored by pharmacists working for the Social Insurance Institution of Finland ${ }^{38,40,59}$, National Agency for Medicines ${ }^{60}$, or at a medical school. ${ }^{38-40}$ The first author was affiliated with a medical school or hospital medical department in 15 publications ${ }^{38-}$ $42,47,50-55,58,61,63$, and affiliated with a nursing school in 10 publications. ${ }^{48,49,56,57,62,64-67,69}$ The first author was affiliated with a dental school in one study. ${ }^{68}$ There were no apparent differences in study design and methodology according to the institutional affiliation of the authors.

\section{Adherence Policy}

The MSAH is responsible for policies in relation to social protection, social welfare and health care. In 2003 the Ministry outlined key pharmaceutical policy objectives in a document entitled Pharmaceutical Policy 2010. ${ }^{3}$ The document stressed the importance of the rational use of medications. Pharmacists were perceived as a potential resource for promoting the rational use of medications. In 2006 the Ministry published a document entitled Safe pharmacotherapy: a national guide for pharmacotherapy in social and health care. ${ }^{72}$ The document highlighted that one way to improve medication safety is for clinicians to provide information and encourage patient participation in treatment decision making.

The Finnish Medicines Agency (Fimea) (comprising the former National Agency for Medicines) operates under the MSAH. It commenced operations in November 2009 and has duties including research and development, and the production and dissemination of information on medicinal products. An objective of Fimea is to improve the effectiveness of pharmaceutical services and pharmacotherapy. Fimea is also responsible for implementing EU guidelines and regulations, and 
approving the content of patient information leaflets (required to be included in dispensed packages of medications in the EU). It is expected that Fimea will take a greater role in ensuring the medication users are placed at the centre of pharmaceutical practice and policy development.

The reimbursement system in Finland has partly been responsible for shaping the way that medication counselling services are offered. Pharmacists are permitted to dispense up to three months supply of a reimbursed prescription medication in a single dispensing. Patients are permitted to collect their repeat supply within a twoweek window prior to the completion of this threemonth period. Pharmacists are required to ensure that patients do not collect their repeat supply early. This means that pharmacists have focused on addressing medication overuse. However, the reimbursement system does not provide similar encouragement for pharmacists to address underuse. The introduction of mandatory generic substitution by pharmacists in 2003 and a reference pricing system in 2009 has also meant that medication counselling is increasingly focused on the cost of medications. ${ }^{73,74}$

\section{Community pharmacy practice related to adherence}

There are no national pharmacy practice programs in Finland that have been specifically developed to monitor or improve medication adherence. However, adherence practice in Finnish pharmacies has been strongly linked to the development of medication counselling services. Finnish pharmacies represent one important setting where strategies to promote medication adherence may be implemented. ${ }^{27}$ Pharmacists in Finland have had a legal and professional obligation to provide medication counselling since 1983. Prior to 1983 pharmacists were not permitted to provide spontaneous medication counselling. Following this change in law there was extensive debate about whether pharmacist-conducted medication counselling would undermine the physician-patient relationship. This meant that many pharmacists were reluctant to provide counselling about adverse drug reactions for fear this might damage the physician-patient relationship and lead to medication non-adherence. The roles and responsibilities of different health professionals in relation to medication counselling has been extensively researched and discussed since this time. $^{75-77}$

Finnish pharmacies have a monopoly on the sale of prescription and non-prescription medications (with exception of nicotine-replacement therapy). ${ }^{78}$ Only pharmacists with a Bachelor's or Master's degree are allowed to sell medications and provide therapeutic advice about prescription and nonprescription medications. ${ }^{27}$ As a result the majority of Finnish pharmacy employees have a degree in pharmacy. Medication counselling initiatives in community pharmacies have included the "Questions to Ask About Your Medicines Campaign", ${ }^{79}$ and the Customized Information for the Benefit of Community Pharmacy Patients (TIPPA) Project. $^{80}$ Research conducted in conjunction with these initiatives revealed that $96 \%$ of Finnish pharmacists agreed or strongly agreed that establishing a therapeutic alliance with patients is a high priority. ${ }^{81}$ However, medication counselling varied according to the therapeutic class of medication, and most commonly related to dosage instructions rather than an in-depth discussion about or monitoring of therapeutic outcomes. ${ }^{82}$ The use of new technologies, such as email and the Internet, as tools to facilitate medication counselling has been the topic of recent research. ${ }^{60,83}$

Special programs have been launched to cater to the needs of particular patient groups. Following the launch of the National Asthma Program in 1994, a Pharmacy Asthma Program was launched in 1997. ${ }^{84}$ The Pharmacy Diabetes Program commenced in 2000 and the Pharmacy Heart Program in $2005 .^{85}$ Pharmacists are instructed to support medication adherence through provision of medication counselling and work together with other health care professionals to develop local models to achieve optimal treatment outcomes. These programs provide a framework rather than stipulating specific adherence monitoring methods. There is also a dose-dispensing service that may be offered to pharmacy clients at high risk of medication non-adherence. ${ }^{27}$ A model for comprehensive medication review involving collaboration between pharmacists and physicians has been developed. ${ }^{86}$ This service may also identify and address medication non-adherence.

\section{FUTURE DIRECTIONS}

A new asthma service is set to be launched in community pharmacies. This program will be based on previous research that investigated the provision of pharmaceutical care for people with asthma ${ }^{21}$, and the EuroPharm Forum model. ${ }^{87} \mathrm{~A}$ new document entitled Pharmaceutical Policy 2020 is due to be published by the MSAH by the end of 2010. It is expected that non-adherence will be recognised as a major reason for failure to achieve medication treatment goals, and that the importance of empowering patients will be further emphasised. It is likely that the importance of health care professionals adopting a concordant approach as a mechanism to better understand and address nonadherence will be highlighted.

The existence of National Prescription Registers in the Nordic countries (Finland, Norway, Sweden, Denmark and Iceland) has facilitated register-based epidemiological research into medication adherence and persistence. $^{18}$ The Nordic Pharmacoepidemiological Network (NorPEN), a new research consortium involving 11 research institutions in the Nordic countries, has been funded by the Nordic Council of Ministers. The aim of the network is to realise the world-unique possibility to carry out population-based cross-country research in pharmacoepidemiology and drug safety. Register-based studies into medication adherence and persistence are one component of this research. This network includes researchers with backgrounds in pharmacy, medicine, epidemiology, statistics and public health. Pharmacists who belong 
to this network are primarily employed by social insurance institutions, national public health institutes, and research centres focused on ageing and pharmacotherapeutics.

\section{METHODOLOGICAL LIMITATIONS}

Only peer-reviewed research articles published in English-language MEDLINE or EMBASE indexed journals from 2000 until present was included in the review of adherence research. Non-English language research on adherence, including master's and doctoral theses, were not identified in the systematic search and were not considered in this review.

\section{CONCLUSIONS}

Adherence research in Finland has focused on understanding the contextual factors that contribute to medication non-adherence. Data have been collected using population-based surveys, qualitative interviews and national health registers. Research has been performed by pharmacy, medical, nursing and dental researchers.
Adherence practice in Finnish community pharmacies has been strongly linked to the development of medication counselling services. Medication adherence is a topic that is integrated into courses or bachelor and master level pharmacy students. The MSAH recognises that nonadherence is a major reason for failing to achieve therapeutic goals. The MSAH also recognises the need for clinicians to empower patients.

\section{ACKNOWLEDGEMENTS}

The authors thank Marika Pohjanoksa-Mäntylä, $\mathrm{PhD}$, and Siv Erikson, MSc(Pharm), for providing information concerning the adherence-related education at the University of Helsinki and Åbo Akademi respectively. The authors also thank Ulla Närhi, PhD, for providing information about pharmaceutical polices related to medication adherence.

\section{CONFLICT OF INTEREST}

None declared.

\section{References}

1. van Dulmen S, Sluijs E, van Dijk L, de Ridder D, Heerdink ER, Bensing J. Patient adherence to medical treatment: a review of reviews. BMC Health Serv Res. 2007;7:55.

2. World Health Organization. Adherence to long term therapies: evidence for action. 2003 Available from: http://www.who.int/chp/knowledge/publications/adherence_report/en/ [Accessed 15 May 2010]

3. Ministry of Social Affairs and Health. Pharmaceutical Policy 2010. 2003 Available from: http://www.stm.fi/c/document_library/get_file?folderld=28707\&name=DLFE3623.pdf\&title=Laakepolitiikka_2010_tiivistelma_fi.pdf [Accessed 15 May 2010]

4. Simpson SH, Eurich DT, Majumdar SR, Padwal RS, Tsuyuki RT, Varney J, Johnson JA. A meta-analysis of the association between adherence to drug therapy and mortality. BMJ. 2006;333:15-20.

5. Horne R, Weinman J, Barber N, Elliott R, Morgan M. Concordance, adherence and compliance in medicine taking. 2005 Available from: http://www.medslearning.leeds.ac.uk/pages/documents/useful_docs/76-final-report\%5B1\%5D.pdf [Accessed 10 July 2010]

6. Aronson JK. Compliance, concordance, adherence. Br J Clin Pharmacol. 2007;63:383-384.

7. Cramer JA, Roy A, Burrell A, Fairchild CJ, Fuldeore MJ, Ollendorf DA, Wong PK. Medication compliance and persistence: terminology and definitions. Value Health. 2008;11:44-47.

8. Caetano PA, Lam JM, Morgan SG. Toward a standard definition and measurement of persistence with drug therapy: Examples from research on statin and antihypertensive utilization. Clin Ther. 2006;28:1411-1424.

9. Hess LM, Raebel MA, Conner DA, Malone DC. Measurement of adherence in pharmacy administrative databases: a proposal for standard definitions and preferred measures. Ann Pharmacother. 2006;40:1280-1288.

10. Kyngäs H, Duffy ME, Kroll T. Conceptual analysis of compliance. J Clin Nurs. 2001;9:5-12.

11. Enlund $\mathrm{H}$, Tuomilehto J, Turakka $\mathrm{H}$. Patient report validated against prescription records for measuring use of and compliance with antihypertensive drugs. Acta Med Scand. 1981;209:271-275.

12. Tuomilehto J, Enlund H, Salonen JT, Nissinen A. Alcohol, patient compliance and blood pressure control in hypertensive patients. Scand J Soc Med. 1982;12:177-181.

13. Enlund $\mathrm{H}$. Measuring patient compliance in antihypertensive therapy-some methodological aspects. J Clin Pharm Ther. 1982;7:43-51.

14. Enlund H, Poston JW. Impact of non-compliance on drug costs. J Soc Adm Pharm. 1987;4:105-111.

15. Hemminki E, Heikkila J. Elderly people's compliance with prescriptions and quality of medication. Scand J Soc Med. 1975;3:87-92.

16. Turakka H, Enlund H. Drug use and prescription compliance by elderly patients. J Clin Pharm Ther. 1978;3:103-112.

17. Bell JS, Airaksinen MS, Lyles A, Chen TF, Aslani P. Concordance is not synonymous with compliance or adherence. $\mathrm{Br}$ J Clin Pharmacol. 2007;64:710-711.

18. Furu K, Wettermark B, Andersen M, Martikainen JE, Almarsdottir AB, Sørensen HT. The Nordic countries as a cohort for pharmacoepidemiological research. Basic Clin Pharmacol Toxicol. 2010;106:86-94.

19. National Institute for Health and Welfare. Finnish Information Centre for Register Research. 2009 Available from: http://retki.stakes.fi/EN/index.htm [Accessed 10 July 2010] 
20. Korhonen T, Huttunen JK, Aro A, Hentinen M, Ihalainen O, Majander H, Siitonen O, Uusitupa M, Pyörälä K. A controlled trial on the effects of patient education in the treatment of insulin-dependent diabetes. Diabetes Care. 1983;6:256-261.

21. Närhi U, Airaksinen M, Enlund H. Pharmacists solving problems in asthma management - experiences from a one-year intervention programme in Finland. Int J Pharm Pract. 2002;10:55-59.

22. Takala J, Niemela N, Rosti J, Sievers K. Improving compliance with therapeutic regimens in hypertensive patients in a community health center. Circulation. 1979;59:540-543.

23. Varis J, Karjalainen S, Korhonen K, Viigimaa M, Port K, Kantola I. Experiences of telemedicine-aided hypertension control in the follow-up of Finnish hypertensive patients. Telemed J E Health. 2009;15:764-769.

24. Joffe G, Takala P, Tchoukhine E, Hakko H, Raidma M, Putkonen H, Eronen M, Räsänen P. Orlistat in clozapine- or olanzapine-treated patients with overweight or obesity: a 16-week randomized, double-blind, placebo-controlled trial. J Clin Psychiatry. 2008;69:706-711.

25. Ringe JD, Christodoulakos GE, Mellstrom D, Petto H, Nickelsen T, Marin F, Pavo I. Patient compliance with alendronate, risedronate and raloxifene for the treatment of osteoporosis in postmenopausal women. Curr Med Res Opin. 2007;23:2677-2687.

26. Ministry of Social Affairs and Health. The Ministry of Social Affairs and Health and its administrative sector 2010 Available from: http://www.stm.fi/en/ministry [Accessed 10 August 2010]

27. Bell JS, Väänänen M, Ovaskainen H, Närhi U, Airaksinen MS. Providing patient care in community pharmacies: practice and research in Finland. Ann Pharmacother. 2007;41:1039-1046.

28. Katajavuori N, Hakkarainen K, Kuosa T, Airaksinen M, Hirvonen J, Holm Y. Curriculum reform in Finnish pharmacy education. Am J Pharm Educ. 2009;73:151.

29. Hautamäki M, Hirvonen J, Airaksinen M. The early years of a pharmacist's career [in Finnish]. Dosis. 2006;22:193-204.

30. Confederation of Unions for Professional and Managerial Staff in Finland (Akava). Professionals of Akava in the job market [in Finnish]. 2009 Available from: http://www.akava.fi/files/67/atm2009nettiin.pdf [Accessed 9 August 2010]

31. Rickles NM, Brown TA, McGivney MS, Snyder ME, White KA. Adherence: a review of education, research, practice and policy in the United States. Pharm Pract (Internet). 2010;8(1):1-17.

32. Aslani P, Krass I. Adherence: a review of education, research, practice and policy in Australia. Pharm Pract (Internet). 2009;7(1):1-10.

33. Noyce PR. Providing patient care through community pharmacies in the UK: policy, practice, and research. Ann Pharmacother. 2007;41:861-868.

34. European Parliament \& Council of the European Union. Directive 2005/36/EC of the European Parliament and of the Council of 7 September 2005 on the recognition of professional qualifications. European Parliament and Council of the European Union. 2005 Available from: http://eur-

lex.europa.eu/LexUriServ/site/en/oj/2005/I_255//_25520050930en00220142.pdf [Accessed 10 July 2010]

35. Katajavuori N, Lindblom-Ylänne S, Hirvonen J. Pharmacy mentors' views of practical training. Res Sci Educ. 2005;35:323-445.

36. Katajavuori N, Lindblom-Ylänne S, Hirvonen J. The significance of practical training in linking theoretical studies with practice. Higher Educ. 2006;51:439-464.

37. Leikola SN, Tuomainen L, Ovaskainen H, Peura S, Sevón-Vilkman N, Tanskanen P, Airaksinen MS. Continuing education course to attain collaborative comprehensive medication review competencies. Am J Pharm Educ. 2009;73:108.

38. Helin-Salmivaara A, Lavikainen P, Korhonen MJ, Halava H, Junnila SY, Kettunen R, Neuvonen PJ, Martikainen JE, Ruokoniemi P, Saastamoinen LK, Virta L, Huupponen R. Long-term persistence with statin therapy: a nationwide register study in Finland. Clin Ther. 2008;30:2228-2240.

39. Helin-Salmivaara A, Lavikainen $P$, Ruokoniemi $P$, Korhonen $M$, Huupponen R. Persistence with statin therapy in diabetic and non-diabetic persons: a nation-wide register study in 1995-2005 in Finland. Diabetes Res Clin Pract. 2009;84:e9-e11.

40. Helin-Salmivaara A, Lavikainen PT, Korhonen MJ, Halava H, Martikainen JE, Saastamoinen LK, Virta L, Klaukka T, Huupponen R. Pattern of statin use among 10 cohorts of new users from 1995 to 2004: a register-based nationwide study. Am J Manag Care. 2010;16:116-122.

41. Nabi H, Vahtera J, Singh-Manoux A, Pentti J, Oksanen T, Gimeno D, Elovainio M, Virtanen M, Klaukka T, Kivimaki M. Do psychological attributes matter for adherence to antihypertensive medication? The Finnish Public Sector Cohort Study. J Hypertens. 2008;26:2236-2243.

42. Pitkala KH, Strandberg TE, Tilvis RS. Interest in healthy lifestyle and adherence to medications: Impact on mortality among elderly cardiovascular patients in the DEBATE Study. Patient Educ Couns. 2007;67:44-49.

43. Enlund $\mathrm{H}$, Jokisalo E, Wallenius S, Korhonen M. Patient-perceived problems, compliance, and the outcome of hypertension treatment. Pharm World Sci. 2001;23:60-64.

44. Jokisalo E, Enlund H, Halonen P, Takala J, Kumpusalo E. Factors related to poor control of blood pressure with antihypertensive drug therapy. Blood Press. 2003;12:49-55.

45. Jokisalo E, Kumpusalo E, Enlund H, Halonen P, Takala J. Factors related to non-compliance with antihypertensive drug therapy. J Hum Hypertens. 2002;16:577-583.

46. Jokisalo E, Kumpusalo E, Enlund H, Takala J. Patients' perceived problems with hypertension and attitudes towards medical treatment. J Hum Hypertens. 2001;15:755-761.

47. Salomaa V, Paakkonen R, Hamalainen H, Niemi M, Klaukka T. Use of secondary preventive medications after the first attack of acute coronary syndrome. Eur J Cardiovasc Prev Rehabil. 2007;14:386-391.

48. Lahdenpera TS, Kyngas HA. Levels of compliance shown by hypertensive patients and their attitude toward their illness. J Adv Nurs. 2001;34:189-195. 
49. Lahdenpera TS, Wright CC, Kyngas HA, Lahdenpera TS, Wright CC, Kyngas HA. Development of a scale to assess the compliance of hypertensive patients. Int J Nurs Stud. 2003;40:677-684.

50. Meretoja A, Roine RO, Kaste M, Erilä T, Hillbom M, Juntunen M, Linna M, Marttila R, Rissanen A, Sivenius J, Häkkinen U. Use and cost of prescription medication before and after ischemic stroke in Finland. Cerebrovasc Dis. 2009;27:232233.

51. Tacke U, Uosukainen H, Kananen M, Kontra K, Pentikänen H. A pilot study about the feasibility and cost-effectiveness of electronic compliance monitoring in substitution treatment with buprenorphine-naloxone combination. J Opiod Manag. 2009;5:321-329.

52. Keranen T, Tuhkasaari M, Kuusisto H. Long-term retention rate of pramipexole in the treatment of Parkinson's disease. Eur J Clin Pharmacol. 2009;65:955-956.

53. Holma IA, Holma KM, Melartin TK, Isometsä ET. Maintenance pharmacotherapy for recurrent major depressive disorder: 5-year follow-up study. Br J Psychiatry. 2008;193:163-164.

54. Melartin TK, Rytsala HJ, Leskela US, Lestela-Mielonen PS, Sokero TP, Isometsa ET. Continuity is the main challenge in treating major depressive disorder in psychiatric care. J Clin Psychiatry. 2005;66:220-227.

55. Kampman O, Laippala P, Vaananen J, Koivisto E, Kiviniemi P, Kilkku N, Lehtinen K. Indicators of medication compliance in first-episode psychosis. Psychiatry Res. 2002;110:39-48.

56. Kyngäs H. Predictors of good compliance in adolescents with epilepsy. Seizure. 2001;10:549-553.

57. Kyngäs H. Compliance with health regimens of adolescents with epilepsy. Seizure. 2000;9:598-604.

58. Sokero P, Melartin T, Rytsälä H, Leskelä U, Lestelä-Mielonen P, Isometsä E. Adequacy of, attitudes toward, and adherence to treatments by suicidal and nonsuicidal depressed patients. J Nerv Ment Dis. 2008;196:223-922.

59. Foulon V, Svala A, Koskinen H, Chen TF, Saastamoinen LK, Bell JS. Impact of regulatory safety warnings on the use of antidepressants among children and adolescents in Finland. J Child Adolesc Psychopharmacol. 2010;20:145-150.

60. Pohjanoksa-Mäntylä M, Saari JK, Närhi U, Pylkkänen K, Airaksinen MS, Bell JS. How and why do people with depression access and utilize online drug information: a qualitative study. J Affect Disord. 2009;114:333-339.

61. Kampman O, Lehtinen K, Lassila V. The reliability of compliance assessments performed by doctors and patients during neuroleptic treatment: a comparison of compliance ratings. Acta Psychiatr Scand. 2001;104:299-304.

62. Kyngäs H, Rissanen M. Support as a crucial predictor of good compliance of adolescents with chronic disease. J Clin Nurs. 2001;10:767-774.

63. Lunnela J, Kääriäinen M, Kyngäs $H$. The views of compliant glaucoma patients on counselling and social support. Scand J Caring Sci. 2010;Mar 3 [Epub ahead of print] DOI 10.1111/j.1471-6712.2009.00739.x:

64. Kyngäs $\mathrm{H}$. Predictors of good adherence of adolescents with diabetes (insulin-dependent diabetes mellitus). Chronic IIIn. 2007;3:20-28.

65. Kyngäs H. Compliance of adolescents with diabetes. J Pediatr Nurs. 2000;15:260-267.

66. Toljamo M, Hentinen M. Adherence to self-care and social support. J Clin Nurs. 2001;10:618-627.

67. Toljamo M, Hentinen M. Adherence to self-care and glycaemic control among people with insulin-dependent diabetes mellitus. J Adv Nurs. 2001;34:780-786.

68. Kneckt MC, Keinänen-Kiukaanniemi SM, Knuuttila ML, Syrjälä AM. Self-esteem as a characteristic of adherence to diabetes and dental self-care regimens. J Clin Periodontol. 2001;28:175-180.

69. Kyngäs H. Compliance of adolescents with rheumatoid arthritis. Int J Nurs Pract. 2000;6:261-267.

70. Morisky DE, Green LW, Levine DM. Concurrent and predictive validity of a self-reported measure of medication adherence. Med Care. 1986;24:67-74.

71. Mahler C, Hermann K, Horne R, Ludt S, Haefeli WE, Szecsenyi J, Jank S. Assessing reported adherence to pharmacological treatment recommendations. Translation and evaluation of the Medication Adherence Report Scale (MARS) in Germany. J Eval Clin Pract. 2010;16:574-579.

72. Ministry of Social Affairs and Health. Safe pharmacotherapy. National guide for pharmacotherapy in social and health care. 2006 Available from: http://www.stm.fi/c/document_library/get_file?folderld=28707\&name=DLFE4090.pdf\&title=Turvallinen_laakehoito_fi.pdf [Accessed 15 May 2010]

73. Aalto-Setälä V, Kanerva R, Bell JS. Drug cost development of citalopram and fluoxetine following the introduction of generic substitution in Finland. Int J Pharm Med. 2007;21:363-368.

74. Timonen J, Karttunen $P$, Bengtström M, Ahonen R. The impact of generic substitution on the turnover and gross margin of pharmaceutical companies a survey 1 year and 5 years after the introduction of generic substitution in Finland. Healthy Policy. 2009;92:116-123.

75. Airaksinen M, Ahonen R, Enlund H. Drug information from pharmacies: desire for more spontaneous information. Med Care. 1993;31:846-850.

76. Airaksinen MS, Vainio KK, Koistinen J, Ahonen R, Wallenius S, Enlund H. Do the public and pharmacists share opinions about drug information. Int Pharm J. 1994;8:168-171.

77. Tanskanen P, Airaksinen M, Tanskanen A, Enlund H. Counselling patients on psychotropic medication: physicians' opinions on the role of community pharmacists. Pharm World Sci. 2000;22:59-61.

78. Kurko T, Linden K, Vasama M, Pietilä K, Airaksinen M. Nicotine replacement therapy practices in Finland one year after deregulation of the product sales - has anything changed from the community pharmacy perspective? Health Policy. 2009;91:277-285.

79. Airaksinen $\mathrm{M}$, Ahonen $\mathrm{R}$, Enlund $\mathrm{H}$. The "questions to ask about your medicines" campaign: an evaluation of pharmacists and the public's response. Med Care. 1998;36:422-427.

80. Kansanaho H, Puumalainen I, Varunki M, Ahonen R, Airaksinen MS. Implementation of a professional program in Finnish community pharmacies in 2000-2002. Patient Educ Couns. 2005;57:272-279. 
81. Kansanaho HM, Puumalainen I, Varunki M, Airaksinen MSA, Aslani P. Attitudes of Finnish community pharmacists toward concordance. Ann Pharmacother. 2004;38:1946-1953.

82. Vainio KK, Airaksinen M, Hyykky TT, Enlund H. Effect of therapeutic class on counselling in community pharmacies. Ann Pharmacother. 2002;36:781-786.

83. Pohjanoksa-Mäntylä MK, Kulovaara H, Bell JS, Enäkoski M, Airaksinen MS. Email medication counseling services provided by Finnish community pharmacies. Ann Pharmacother. 2008;42:1782-1790.

84. Haahtela T, Klaukka T, Koskela K, Erhola M, Laitinen LA. Asthma programme in Finland: a community problem needs community solutions. Thorax. 2001;56:806-814.

85. Parkkamäki S, Ritsilä A-L. Impact of a multi-professional local program on the prevention and care of type 2 diabetes in the Haukivuori community [in Finnish]. Dosis. 2004;20:163-171.

86. Peura S, Ovaskainen H, Lehtonen A, Wiberg I, Airaksinen MS, Hakkarainen K, Tanskanen P, Sevon-Vilkman N, Tuomainen L. Comprehensive medication review involving collaboration between pharmacists and physicians experiences developing the procedure in Finland [in Finnish]. Dosis. 2007;23:20-28.

87. EuroPharm Forum and World Health Organization Regional Office for Europe. Pharmacy-based asthma services protocol and guidelines. 1998. Copenhagen, Denmark. 


\begin{tabular}{|c|c|c|c|c|}
\hline University & $\begin{array}{l}\text { Degree } \\
\text { (year) }\end{array}$ & $\begin{array}{l}\text { Obligatory or } \\
\text { elective }\end{array}$ & $\begin{array}{l}\text { Course name and credit } \\
\text { points (ECTS) }\end{array}$ & Content specific to adherence \\
\hline \multirow[t]{5}{*}{ Åbo Akademi } & BSc (1) & Obligatory & $\begin{array}{l}\text { Medication use and patient } \\
\text { counselling ( } 3 \text { ) }\end{array}$ & $\begin{array}{l}\text { Concept of compliance, concordance and empowerment and related factors. Students perform } \\
\text { literature search, produce report, and participate in group discussions }\end{array}$ \\
\hline & $\mathrm{BSc}(2)$ & Obligatory & $\begin{array}{l}\text { Pharmacy management and } \\
\text { economy (3) }\end{array}$ & $\begin{array}{l}\text { Above concepts from perspective of customers and pharmacies. Introduction to role of } \\
\text { pharmacist and the importance of adherence counselling. Content related to importance of } \\
\text { medication adherence for patient's health and health costs }\end{array}$ \\
\hline & BSc (3) & Obligatory & Pharmacotherapy (3) & \multirow[t]{2}{*}{$\begin{array}{l}\text { Adherence related issues are discussed throughout the course. Consideration given to patient } \\
\text { groups with special needs, e.g. children and older people }\end{array}$} \\
\hline & $\mathrm{BSc}(2)$ & Obligatory & $\begin{array}{l}\text { Pharmacology of over-the- } \\
\text { counter medications (2) }\end{array}$ & \\
\hline & $\mathrm{BSc}(1-3)$ & Obligatory & $\begin{array}{l}\text { Courses in pharmaceutics and } \\
\text { biopharmaceutics (various) }\end{array}$ & $\begin{array}{l}\text { Adherence related issues discussed in courses (e.g. the importance of dosage form for } \\
\text { medication adherence) }\end{array}$ \\
\hline \multirow[t]{7}{*}{$\begin{array}{l}\text { University of } \\
\text { Eastern } \\
\text { Finland }\end{array}$} & $\mathrm{BSc}(1)$ & Obligatory & Medicines in healthcare (3.5) & $\begin{array}{l}\text { Correct and incorrect use of medications, problems related to medication use, patient counselling } \\
\text { in community pharmacies, clinical pharmacy and pharmaceutical care, conducting and reporting } \\
\text { a patient interview }\end{array}$ \\
\hline & $\mathrm{BSc}(2-3)$ & Obligatory & $\begin{array}{l}\text { Communication skills and } \\
\text { patient counselling in a } \\
\text { pharmacy }(8)\end{array}$ & $\begin{array}{l}\text { Adherence related issues are discussed throughout the course. Includes practical classes in } \\
\text { which students need to provide counselling that supports adherence }\end{array}$ \\
\hline & $\mathrm{BSc}(2-3)$ & Obligatory & Pharmacotherapy (6) & Adherence related issues are discussed throughout the course \\
\hline & $\mathrm{BSc}(3)$ & Obligatory & $\begin{array}{l}\text { Current issues in health care } \\
(1.5)\end{array}$ & $\begin{array}{l}\text { Students prepare and present in-house training sessions. Themes introduced in the Medicines in } \\
\text { Healthcare course are further developed. There is a special focus on children, older people and } \\
\text { other specific patient groups }\end{array}$ \\
\hline & MSc (4) & $\begin{array}{l}\text { Obligatory for } \\
\text { students specialising } \\
\text { in social pharmacy }\end{array}$ & Theoretical social pharmacy (6) & $\begin{array}{l}\text { History of social pharmacy research (in which compliance has been an important topic). } \\
\text { Concepts and theories of compliance, adherence, concordance and empowerment are covered }\end{array}$ \\
\hline & MSc (4-5) & Elective & Geriatric pharmacotherapy (2) & Adherence related issues are discussed throughout the course \\
\hline & BSc \& MSc & Obligatory & $\begin{array}{l}\text { Courses in pharmacology and } \\
\text { biopharmaceutics (various) }\end{array}$ & Adherence related issues are covered to some extent \\
\hline \multirow[t]{6}{*}{$\begin{array}{l}\text { University of } \\
\text { Helsinki }\end{array}$} & $\mathrm{BSc}(2)$ & Obligatory & $\begin{array}{l}\text { Patient education and } \\
\text { counselling ( } 3)\end{array}$ & \multirow{3}{*}{$\begin{array}{l}\text { All } 3 \text { courses are integrated and include some content specific to adherence including: an } \\
\text { overview of concordance, empowerment, and self-management, epidemiology of adherence, } \\
\text { different forms of non-adherence, determinants of adherence, ways to improve adherence in a } \\
\text { pharmacy, relation between medication information and adherence, lifestyle issues that relate to } \\
\text { adherence and medication therapy. There are self-learning materials for students that include } \\
\text { content specific to adherence, concordance, empowerment and self-management }\end{array}$} \\
\hline & $\mathrm{BSc}(2)$ & Obligatory & Counselling skills (1) & \\
\hline & $\mathrm{BSc}(2)$ & Obligatory & Pharmacotherapy I (3) & \\
\hline & BSc (3) & Obligatory & Medicines in healthcare (5) & $\begin{array}{l}\text { Teaching related to the above concepts is covered in greater depth. Medication adherence } \\
\text { among special patient populations (e.g. older people, and people with depression) is discussed. } \\
\text { More focus is put on research and theories related to medication use, adherence and } \\
\text { concordance }\end{array}$ \\
\hline & BSc (3) & Obligatory & Pharmacotherapy II (3) & $\begin{array}{l}\text { Topics covered during Pharmacotherapy I course are covered in greater depth with prescription } \\
\text { medications and long-term therapy }\end{array}$ \\
\hline & MSc (4) & $\begin{array}{l}\text { Obligatory for } \\
\text { students specialising } \\
\text { in social pharmacy. } \\
\text { Otherwise an } \\
\text { elective course }\end{array}$ & $\begin{array}{l}\text { Medication review and clinical } \\
\text { pharmacy (4) }\end{array}$ & $\begin{array}{l}\text { Topics covered include: determinants of adherence/non-adherence, ways to improve adherence, } \\
\text { instruments/scales to measure adherence in medication reviews }\end{array}$ \\
\hline
\end{tabular}




\begin{tabular}{|l|l|l|l|l|}
\hline Table 1. Pharmacy education related to adherence in Finland \\
\hline University & $\begin{array}{l}\text { Degree } \\
\text { (year) }\end{array}$ & $\begin{array}{l}\text { Obligatory or } \\
\text { elective }\end{array}$ & $\begin{array}{l}\text { Course name and credit } \\
\text { points (ECTS) }\end{array}$ & Content specific to adherence \\
\hline $\begin{array}{l}\text { University of } \\
\text { Helsinki }\end{array}$ & MSc (4-5) & $\begin{array}{l}\text { Obligatory and } \\
\text { elective courses }\end{array}$ & $\begin{array}{l}\text { Social pharmacy courses: } \\
\text { Health Promotion (4) } \\
\text { Smoking cessation (3-4) } \\
\text { Drug information and drug } \\
\text { information services (4) } \\
\text { Clinical pharmacy (3) }\end{array}$ & $\begin{array}{l}\text { Adherence, concordance, empowerment, and self-management discussed throughout the } \\
\text { courses }\end{array}$ \\
& MSc (4-5) & $\begin{array}{l}\text { Obligatory for } \\
\text { students specialising } \\
\text { in pharmacology }\end{array}$ & Clinical pharmacology (3 op) & Adherence related issues discussed throughout the course \\
\cline { 2 - 5 } & & \\
\hline ECTS=European Credit Transfer and Accumulation System (1 credit equivalent to 26.7 hours work) \\
\hline
\end{tabular}

\begin{tabular}{|c|c|c|c|c|}
\hline $\begin{array}{l}\text { Author, date and } \\
\text { reference number }\end{array}$ & $\begin{array}{c}\text { Study design } \\
\text { and/or data source }\end{array}$ & Study sample & Relevant outcome measure(s) & Main findings \\
\hline Foulon et al. $2010^{59}$ & $\begin{array}{l}\text { Register-based } \\
\text { study (National } \\
\text { Prescription } \\
\text { Register) }\end{array}$ & $\begin{array}{l}\text { Children and adolescents } \\
\text { aged } \leq 19(\mathrm{n}=27,676) \text { who } \\
\text { received a reimbursed } \\
\text { antidepressant from 1998- } \\
2005\end{array}$ & $\begin{array}{l}\text { Percentage of children and } \\
\text { adolescents dispensed only one } \\
\text { antidepressant prescription } \\
\text { (maximum duration } 3 \text { months) (S) }\end{array}$ & $\begin{array}{l}31 \% \text { of children and adolescents received only one reimbursed } \\
\text { antidepressant prescription (maximum persistence } 3 \text { months) }\end{array}$ \\
\hline Lunnela et al. $2010^{63}$ & $\begin{array}{l}\text { Qualitative } \\
\text { interviews }\end{array}$ & $\begin{array}{l}12 \text { compliant patients with } \\
\text { glaucoma }\end{array}$ & $\begin{array}{l}\text { Perceived importance of education } \\
\text { and social support received from } \\
\text { healthcare personnel, relatives and } \\
\text { peers among compliant patients with } \\
\text { glaucoma }\end{array}$ & $\begin{array}{l}\text { Individual variation in the need for education and support in relation } \\
\text { to compliance. Important to receive education and support during } \\
\text { initial stages of illness and following treatment change }\end{array}$ \\
\hline $\begin{array}{l}\text { Helin-Salmivaara et al. } \\
2010^{0}\end{array}$ & $\begin{array}{l}\text { Register-based } \\
\text { study (National } \\
\text { Prescription } \\
\text { Register) }\end{array}$ & $\begin{array}{l}490,024 \text { new users of statins } \\
\text { in yearly cohorts from } 1995 \\
\text { to } 2005\end{array}$ & $\begin{array}{l}\text { One year persistence with statin } \\
\text { therapy. Proportion of days covered } \\
\text { among patients who discontinued } \\
\text { within } 365 \text { days since initiation }\end{array}$ & $\begin{array}{l}\text { Compared with the } 1995 \text { cohort, the } 1998,1999,2000,2001,2002 \text {, } \\
2003 \text {, and } 2004 \text { cohorts were less likely to discontinue treatment } \\
\text { within } 12 \text {-months. Hazard ratios for discontinuation ranged from } 0.91 \\
(95 \% \mathrm{Cl}, 0.88-0.94) \text { in } 1998 \text { to } 0.80(95 \% \mathrm{Cl}, 0.78-0.83) \text { in } 2004\end{array}$ \\
\hline Meretoja et al. $2009^{50}$ & $\begin{array}{l}\text { Register linkage } \\
\text { study (National } \\
\text { Prescription } \\
\text { Register, National } \\
\text { Hospital Discharge } \\
\text { Register) }\end{array}$ & $\begin{array}{l}5,586 \text { patients discharged } \\
\text { from hospital following } \\
\text { admission for a stroke in } \\
2005\end{array}$ & $\begin{array}{l}\text { Reimbursed purchases for } \\
\text { secondary preventative (warfarin, } \\
\text { aspirin+dipyridamole or clopidogrel) } \\
\text { and cardiovascular medications in } \\
\text { pharmacies pre and post hospital } \\
\text { admission for stroke }\end{array}$ & $\begin{array}{l}33 \% \text { of patients did not collect prescription(s) for any secondary } \\
\text { preventative medication following hospital discharge. The prevalence } \\
\text { of antihypertensive use increased from } 64 \% \text { pre-stroke to } 78 \% \text { post- } \\
\text { stroke. The prevalence of statin use increased from } 25 \% \text { pre-stroke } \\
\text { to } 58 \% \text { post-stroke }\end{array}$ \\
\hline Tacke et al. $2009^{51}$ & Observational study & $\begin{array}{l}12 \text { patients who received } \\
\text { buprenorphine/naloxone for } \\
6 \text { days in a compliance- } \\
\text { monitoring device }\end{array}$ & $\begin{array}{l}\text { Regularity of daily administration, } \\
\text { treatment costs, and patients' views } \\
\text { on acceptability and drug diversion }\end{array}$ & $\begin{array}{l}\text { Six patients demonstrated good compliance and } 2 \text { patients } \\
\text { demonstrated minor irregularities. Seven patients reported the } \\
\text { package was too large, } 5 \text { patients positive treatment influence, } 3 \\
\text { patients that it stopped diversion and } 1 \text { patient thought the package } \\
\text { was difficult to use }\end{array}$ \\
\hline
\end{tabular}




\begin{tabular}{|c|c|c|c|c|}
\hline $\begin{array}{l}\text { Author, date and } \\
\text { reference number }\end{array}$ & $\begin{array}{l}\text { Study design } \\
\text { and/or data source }\end{array}$ & Study sample & Relevant outcome measure(s) & Main findings \\
\hline Keränen et al. $2009^{52}$ & $\begin{array}{l}\text { Retrospective } \\
\text { medical record } \\
\text { review }\end{array}$ & $\begin{array}{l}94 \text { patients (mean age } 59 \\
\text { years) with Parkinson's } \\
\text { Disease }\end{array}$ & $\begin{array}{l}\text { Persistence with pramipexole at } 1,3 \\
\text { and } 6 \text { years based on physicians } \\
\text { records at university hospital }\end{array}$ & $\begin{array}{l}76 \%, 63 \% \text { and } 63 \% \text { of patients were still taking pramipexole at } 1,3 \\
\text { and } 6 \text { years respectively. Predictors of discontinuation were } \\
\text { orthostatic hypotension and entacapone treatment prior to initiation } \\
\text { of pramipexole }\end{array}$ \\
\hline $\begin{array}{l}\text { Helin-Salmivaara et al. } \\
2009^{39}\end{array}$ & $\begin{array}{l}\text { Register-based } \\
\text { study (National } \\
\text { Prescription } \\
\text { Register) }\end{array}$ & $\begin{array}{l}562,598 \text { new users of statins } \\
\text { in Finland from 1995-2005 }\end{array}$ & $\begin{array}{l}\text { Discontinuation defined using } \\
\text { period covered by the last } \\
\text { prescription followed by a tablet-free } \\
\text { gap exceeding } 270 \text { days }\end{array}$ & $\begin{array}{l}\text { Persons with diabetes (15\%) were more likely to be taking a statin } \\
\text { one-year after initiation compared to those without diabetes }(77.1 \% \\
\text { vs. } 73.8 \%) \text {. Risk for discontinuation was lower among male than } \\
\text { female diabetic persons OR } 0.94(95 \% \mathrm{Cl} 0.91-0.96)\end{array}$ \\
\hline $\begin{array}{l}\text { Pohjanoksa-Mäntylä et al. } \\
2009^{60}\end{array}$ & $\begin{array}{l}\text { Qualitative } \\
\text { interviews }\end{array}$ & $\begin{array}{l}29 \text { people with depression } \\
\text { who had used the Internet to } \\
\text { access drug information }\end{array}$ & $\begin{array}{l}\text { Self-reported impact of using online } \\
\text { drug information on medication } \\
\text { taking behaviour (S) }\end{array}$ & $\begin{array}{l}\text { Self-reported impacts of utilising online drug information included } \\
\text { being reassured, deciding to change a dose, to discontinue a } \\
\text { medication and to suggest a new medication to a physician }\end{array}$ \\
\hline Nabi et al. $2008^{41}$ & $\begin{array}{l}\text { Register-based } \\
\text { study (National } \\
\text { Prescription } \\
\text { Register) combined } \\
\text { with postal survey }\end{array}$ & $\begin{array}{l}\text { 1,021 hypertensive patients } \\
\text { aged } 26-63 \text { years } \\
\text { participating in the Finnish } \\
\text { Public Sector Cohort Study }\end{array}$ & $\begin{array}{l}\text { Treatment adherence defined } \\
\text { according to } 12 \text {-month reimbursed } \\
\text { medication supply ( } 0 \text { days non- } \\
\text { adherence, } 1-364 \text { days partial } \\
\text { adherence, } 365 \text { days adherence). } \\
\text { Sense of coherence measured using } \\
\text { Orientation to Life Questionnaire }\end{array}$ & $\begin{array}{l}60 \% \text { of patients were adherent, } 36 \% \text { partially adherent, and } 4 \% \\
\text { nonadherent. A high sense of coherence was associated with lower } \\
\text { odds of being nonadherent (OR 0.55; } 95 \% \mathrm{Cl}, 0.31-0.96 \text { ) }\end{array}$ \\
\hline Holma et al. $2008^{53}$ & $\begin{array}{l}\text { Prospective cohort } \\
\text { study (Vantaa } \\
\text { Depression Study) }\end{array}$ & $\begin{array}{l}218 \text { patients with major } \\
\text { depressive disorder }\end{array}$ & $\begin{array}{l}\text { Antidepressant adherence } \\
\text { categorised as regular, somewhat } \\
\text { irregular, very irregular, or not at all }\end{array}$ & $\begin{array}{l}\text { Antidepressant adherence in acute treatment phase independently } \\
\text { predicted maintenance treatment (OR } 3.18 ; 95 \% \mathrm{Cl} 1-12-9.03)\end{array}$ \\
\hline $\begin{array}{l}\text { Helin-Salmivaara et al. } \\
2008^{38}\end{array}$ & $\begin{array}{l}\text { Register-based } \\
\text { study (National } \\
\text { Prescription } \\
\text { Register) } \\
\end{array}$ & $\begin{array}{l}18,072 \text { new users of statins } \\
\text { in } 1995\end{array}$ & $\begin{array}{l}\text { Persistence (time from initiation to } \\
\text { discontinuation) and adherence } \\
\text { (proportion of days covered by } \\
\text { treatment) }\end{array}$ & $\begin{array}{l}\text { 10-year statin persistence in general population was } 44 \% \text {. Persons } \\
\text { aged } 45-74 \text { years at initiation and those with } \geq 1 \text { prescription for } \\
\text { another cardiovascular drug most likely to continue to fifth year. } \\
\text { Adherence was highest among persistent users }(94 \%)\end{array}$ \\
\hline Sokero et al. $2008^{58}$ & $\begin{array}{l}\text { Prospective cohort } \\
\text { study (Vantaa } \\
\text { Depression Study) }\end{array}$ & $\begin{array}{l}218 \text { patients with major } \\
\text { depressive disorder (mean } \\
\text { age } 41 \text { years, } 91 \text { not } \\
\text { suicidal, } 92 \text { suicidal ideation, } \\
34 \text { history of suicide } \\
\text { attempts). }\end{array}$ & $\begin{array}{l}\text { Antidepressant adherence } \\
\text { categorised as regular, somewhat } \\
\text { irregular, very irregular, or not at all } \\
\text { on basis of patient interview }\end{array}$ & $\begin{array}{l}\text { Self-reported adherence did not differ between those patients who } \\
\text { were not suicidal }(69 \%) \text {, had suicidal ideation }(71 \%) \text { or had a history } \\
\text { of suicide attempts }(70 \%)\end{array}$ \\
\hline Salomaa et al. $2007^{4 \prime}$ & $\begin{array}{l}\text { Register linkage } \\
\text { study (cause of } \\
\text { death register, } \\
\text { hospital discharge } \\
\text { register, National } \\
\text { Prescription } \\
\text { Register) }\end{array}$ & $\begin{array}{l}\text { All patients aged } 35-74 \\
\text { years hospitalized for the } \\
\text { first nonfatal acute coronary } \\
\text { syndrome in Finland during } \\
1995-2003(n=53353)\end{array}$ & $\begin{array}{l}\text { Medication persistence at } 3 \text { months } \\
\text { assessed using National } \\
\text { Prescription Register }\end{array}$ & $\begin{array}{l}28 \% \text { and } 15 \% \text { of the patients did not receive hypolipidemic } \\
\text { medications or beta-blockers after coronary syndrome and a further } \\
6 \% \text { and } 10 \% \text { discontinued these medications } 3 \text { months later }\end{array}$ \\
\hline Pitkälä et al. $2007^{42}$ & $\begin{array}{l}\text { Prospective study } \\
\text { among participants } \\
\text { in randomised } \\
\text { controlled trial }\end{array}$ & $\begin{array}{l}400 \text { cardiovascular patients } \\
\text { ( }>74 \text { years) }\end{array}$ & $\begin{array}{l}\text { Institutionalisation or death at } 4.5 \\
\text { year follow-up }\end{array}$ & $\begin{array}{l}\text { Skepticism towards medications ( } \mathrm{HR} 2.73,95 \% \mathrm{Cl} 1.11-6.52) \text { and } \\
\text { non-adherence (HR } 6.24,95 \% \mathrm{Cl} 1.88-20.67) \text { associated with } \\
\text { institutionalisation or death at } 4.5 \text { year follow-up }\end{array}$ \\
\hline
\end{tabular}




\begin{tabular}{|c|c|c|c|c|}
\hline $\begin{array}{l}\text { Author, date and } \\
\text { reference number }\end{array}$ & $\begin{array}{c}\text { Study design } \\
\text { and/or data source }\end{array}$ & Study sample & Relevant outcome measure(s) & Main findings \\
\hline Kyngäs et al. $2007^{64}$ & $\begin{array}{l}\text { Cross-sectional } \\
\text { postal survey using } \\
\text { health register as a } \\
\text { sampling frame }\end{array}$ & $\begin{array}{l}300 \text { children and } \\
\text { adolescents aged } 13-17 \\
\text { years with insulin dependent } \\
\text { diabetes ( } 97 \% \text { response } \\
\text { rate) }\end{array}$ & $\begin{array}{l}\text { Adherence (including medication } \\
\text { adherence) coded as a dichotomous } \\
\text { variable }\end{array}$ & $\begin{array}{l}\text { Threat to mental wellbeing OR } 7.68(95 \% \mathrm{Cl} 3.95-13.42) \text {, support } \\
\text { from physicians OR } 6.69(95 \% \mathrm{Cl} 3.70-11.46) \text {, support from nurses } \\
\text { OR } 6.28(95 \% \mathrm{Cl} 2.78-16.25) \text { and motivation OR } 5.52(95 \% \mathrm{Cl} 3.70- \\
11.46) \text { were factors that significantly predicted adherence }\end{array}$ \\
\hline Melartin et al. $2005^{54}$ & $\begin{array}{l}\text { Prospective cohort } \\
\text { study (Vantaa } \\
\text { Depression Study) }\end{array}$ & $\begin{array}{l}269 \text { patients with DSM-IV } \\
\text { major depressive disorder }\end{array}$ & $\begin{array}{l}\text { Adherence and attitudes toward } \\
\text { antidepressants among } 198 \text { patients } \\
\text { followed for } 18 \text { months }\end{array}$ & $\begin{array}{l}88 \% \text { patients received antidepressants in acute phase, } 49 \% \\
\text { terminated treatment prematurely. Termination was associated with } \\
\text { major depressive episodes explained by fear of dependence and } \\
\text { antidepressant side-effects }\end{array}$ \\
\hline Lahdenperä et al. $2003^{49}$ & $\begin{array}{l}\text { Development of a } \\
\text { compliance scale } \\
\text { using a self- } \\
\text { completed patient } \\
\text { survey }\end{array}$ & $\begin{array}{l}\text { A convenience sample of } \\
103 \text { patients with } \\
\text { hypertension aged } 24-65 \\
\text { years from } 5 \text { health centres }\end{array}$ & $\begin{array}{l}\text { Principal components analysis of } \\
\text { compliance survey }\end{array}$ & $\begin{array}{l}\text { Data supported five subscales labelled lifestyle, intention, attitudes, } \\
\text { responsibility and smoking. There was a correlation between } \\
\text { medication use and attitudes }(r=0.282, p<0.015) \text {. However, the two } \\
\text { medication-related items were excluded from final scale because } \\
27 \% \text { of patients did not take medication. }\end{array}$ \\
\hline Jokisalo et al. $2003^{44}$ & $\begin{array}{l}\text { Cross-sectional mail } \\
\text { surveys and health } \\
\text { examination of } \\
\text { general practice } \\
\text { patients }\end{array}$ & $\begin{array}{l}1782(80 \%) \text { hypertensive } \\
\text { patients from } 26 \text { health } \\
\text { centres during one week in } \\
1996\end{array}$ & $\begin{array}{l}\text { Factors associated with poor blood } \\
\text { pressure control (BP } \geq 140 / 90 \\
\mathrm{mmHg})\end{array}$ & $\begin{array}{l}\text { Non-compliance in men was associated with poor blood pressure } \\
\text { control. Hopelessness towards hypertension (OR, } 2.16 ; 95 \% \mathrm{Cl} \\
1.20-3.88), \text { medium and high levels of frustration with treatment (OR, } \\
1.50 ; 95 \% \mathrm{Cl} 1.04-2.18 \text { and OR } 1.83 ; 95 \% \mathrm{Cl} 0.98-3.44) \text { were } \\
\text { associated with poor control. Older age and monotherapy were also } \\
\text { associated with poor blood pressure control. }\end{array}$ \\
\hline Jokisalo et al. $2002^{45}$ & $\begin{array}{l}\text { Cross-sectional mail } \\
\text { surveys and health } \\
\text { examination of } \\
\text { general practice } \\
\text { patients }\end{array}$ & $\begin{array}{l}1782(80 \%) \text { hypertensive } \\
\text { patients from } 26 \text { health } \\
\text { centres during one week in } \\
1996, \text { of whom } 1561 \text { on } \\
\text { antihypertensive medication }\end{array}$ & $\begin{array}{l}\text { Self-reported non-compliance with } \\
\text { antihypertensive medication (took } \\
\text { medication 'less often than } \\
\text { prescribed during the last year' or } \\
\text { 'modification of dosage instructions') }\end{array}$ & $\begin{array}{l}\text { Perceived health system-related problems (OR } 4.77,95 \% \mathrm{Cl} 2.76- \\
8.26) \text { and patient-related problems (OR } 3.23,95 \% \mathrm{Cl} 1.79-5.81) \\
\text { associated with self-reported non-compliance. Adverse drug } \\
\text { reactions also associated with non-compliance (OR } 1.41,95 \% \mathrm{Cl} \\
1.03-1.94)\end{array}$ \\
\hline Kampman et al. $2002^{55}$ & $\begin{array}{l}\text { Prospective } \\
\text { interview study }\end{array}$ & $\begin{array}{l}59 \text { patients with a first-onset } \\
\text { psychosis during their initial } \\
\text { phase of treatment }\end{array}$ & $\begin{array}{l}\text { Observed compliance during the first } \\
3 \text { months of treatment assessed } \\
\text { using patient record data }\end{array}$ & $\begin{array}{l}\text { Determinants of observed non-compliance included harmful side } \\
\text { effects, male sex, lack of social activities, low PANSS score for } \\
\text { positive symptoms, high PANSS total score and young age. The } \\
\text { duration of untreated psychosis was not associated with compliance }\end{array}$ \\
\hline Närhi et al. $2002^{21}$ & $\begin{array}{l}\text { One-year } \\
\text { intervention study in } \\
\text { four community } \\
\text { pharmacies }\end{array}$ & $\begin{array}{l}31 \text { patients (aged } 20-64 \\
\text { years) with perceived } \\
\text { problems in asthma } \\
\text { management }\end{array}$ & $\begin{array}{l}\text { Perceived problems in asthma self- } \\
\text { management at baseline, } 4 \text { months, } \\
8 \text { months and } 12 \text { months }\end{array}$ & $\begin{array}{l}\text { Of } 28 \text { patients who completed the intervention, } 17 \text { patients self- } \\
\text { reported problems with medications at baseline (including difficulty } \\
\text { remembering to take medications, and considering medications } \\
\text { unpleasant) compared to } 4 \text { patients at the } 12 \text {-month follow-up }\end{array}$ \\
\hline Kneckt et al. $2001^{68}$ & $\begin{array}{l}\text { Cross-sectional } \\
\text { patient self- } \\
\text { completed survey }\end{array}$ & $\begin{array}{l}149 \text { patients with insulin } \\
\text { dependent diabetes mellitus }\end{array}$ & $\begin{array}{l}\text { Adherence to insulin regimen } \\
\text { (adjusting injections to meal times } \\
\text { and adjusting insulin dose to } \\
\text { exercise). Self-esteem was } \\
\text { assessed using 8-point scale }\end{array}$ & $\begin{array}{l}64 \% \text { of patients with diabetes self-reported good adherence to their } \\
\text { insulin regimen. High self-esteem was associated with self-reported } \\
\text { adherence to insulin regimen }(p=0.005)\end{array}$ \\
\hline Kampman et al. $2001^{61}$ & $\begin{array}{l}\text { Prospective } \\
\text { interview study }\end{array}$ & $\begin{array}{l}100 \text { hospital inpatients and } \\
\text { outpatients receiving } \\
\text { neuroleptic medication } \\
\text { (mean age } 37.6 \text { years, age } \\
\text { range } 16-63 \text { years) }\end{array}$ & $\begin{array}{l}\text { Discrepancy in compliance } \\
\text { assessments performed by } \\
\text { physicians and patient self-reported } \\
\text { compliance }\end{array}$ & $\begin{array}{l}\text { Patient characteristics explaining discrepancy in assessments } \\
\text { included mania, high neuroleptic dose, female gender, low education } \\
\text { level, and attitudes toward neuroleptic treatment }\end{array}$ \\
\hline
\end{tabular}




\begin{tabular}{|c|c|c|c|c|}
\hline $\begin{array}{l}\text { Author, date and } \\
\text { reference number }\end{array}$ & $\begin{array}{c}\text { Study design } \\
\text { and/or data source }\end{array}$ & Study sample & Relevant outcome measure(s) & Main findings \\
\hline Jokisalo et al. $2001^{46}$ & $\begin{array}{l}\text { Cross-sectional mail } \\
\text { surveys and health } \\
\text { examination of } \\
\text { general practice } \\
\text { patients }\end{array}$ & $\begin{array}{l}1782(80 \%) \text { hypertensive } \\
\text { patients from } 26 \text { health } \\
\text { centres during one week in } \\
1996, \text { of whom } 1561 \text { on } \\
\text { antihypertensive medication }\end{array}$ & $\begin{array}{l}14 \text { self-reported problem indices } \\
\text { formulated from } 82 \text { items about } \\
\text { experiences in relation to } \\
\text { hypertension treatment }\end{array}$ & $\begin{array}{l}\text { Problems included lack of motivation for follow-up ( } 72 \%) \text {, difficultly } \\
\text { accepting being hypertensive }(66 \%) \text {, careless attitude towards } \\
\text { hypertension }(63 \%) \text {, lack of information ( } 56 \%) \text {, and hopelessness, } \\
\text { impact on sexual function and lack of support by health care } \\
\text { personnel (33\%). The least frequent problems included modification } \\
\text { of dosage instructions. The number of problems per person ranged } \\
\text { from } 0-13, \text { mean } 4.9\end{array}$ \\
\hline Enlund et al. $2001^{43}$ & $\begin{array}{l}\text { Cross-sectional } \\
\text { survey of patients of } \\
9 \text { community } \\
\text { pharmacies }\end{array}$ & $\begin{array}{l}971 \text { patients aged }<75 \text { years } \\
\text { receiving long-term } \\
\text { treatment with } \\
\text { antihypertensive } \\
\text { medications between May } \\
\text { and September of } 1996 \text {, of } \\
\text { whom } 482(56 \%) \text { completed } \\
\text { the questionnaire }\end{array}$ & $\begin{array}{l}\text { Self-reported self-initiated } \\
\text { modification of dosage instructions } \\
\text { (often, sometimes, no) with often } \\
\text { and sometimes combined to form a } \\
\text { dichotomous variable (modifiers and } \\
\text { non-modifiers). Self-reported } \\
\text { hypertension treatment problems } \\
\text { (symptoms of hypertension, adverse } \\
\text { drug effects, perceived negative } \\
\text { patient role, memory problems, } \\
\text { interference with daily routines, had } \\
\text { to give up pleasant } \\
\text { activities/interference with hobbies) }\end{array}$ & $\begin{array}{l}31 \% \text { of males and } 21 \% \text { of females self-reported they modified their } \\
\text { dosage instructions. Patients with } 3+\text { hypertension treatment } \\
\text { problems and those with an academic education were significantly } \\
\text { more likely to have modified their dosage instructions than those } \\
\text { without problems (OR } 4.79,95 \% \mathrm{Cl} 2.36-9.73 \text { ) and (OR } 2.69,95 \% \\
\mathrm{Cl} 1.27-5.70 \text { ) }\end{array}$ \\
\hline $\begin{array}{l}\text { Lahdenperä \& Kyngäs. } \\
2001^{48}\end{array}$ & $\begin{array}{l}\text { Interviews with } \\
\text { participants in a } \\
\text { compliance } \\
\text { intervention } \\
\text { comprising a } \\
\text { multimedia computer } \\
\text { program and } \\
\text { lifestyle counselling }\end{array}$ & $\begin{array}{l}21 \text { patients with } \\
\text { hypertension aged } 16-64 \\
\text { years who had been taking } \\
\text { medication for less than one } \\
\text { year or not at all }\end{array}$ & $\begin{array}{l}\text { Meaning of compliance to patients } \\
\text { with hypertension, and attitude of } \\
\text { patients toward their illness (S) }\end{array}$ & $\begin{array}{l}\text { Four levels of compliance detected (subconscious, cognitive, action } \\
\text { and attitudinal). Four types of attitudes toward illness detected } \\
\text { (careless, serious, well adjusted, frustrated) }\end{array}$ \\
\hline $\begin{array}{l}\text { Toljamo \& Hentinen. } \\
2001^{66}\end{array}$ & $\begin{array}{l}\text { Cross-sectional mail } \\
\text { survey }\end{array}$ & $\begin{array}{l}213 \text { people with insulin- } \\
\text { treated diabetes aged } 17-65 \\
\text { years who visited health } \\
\text { centre or hospital }(76 \% \\
\text { response rate) }\end{array}$ & $\begin{array}{l}\text { Adherence to self-care, difficulties in } \\
\text { self-care, perceived receipt of social } \\
\text { support (S) }\end{array}$ & $\begin{array}{l}10 \% \text { of respondents reported sometimes, often or always } \\
\text { experiencing difficulties with insulin treatment at home, while } 43 \% \\
\text { experienced difficulties when not at home. Insulin therapy was not } \\
\text { perceived as the most difficult aspect of self-care. There was an } \\
\text { overall relationship between poor self-care and poor metabolic } \\
\text { control }\end{array}$ \\
\hline $\begin{array}{l}\text { Toljamo \& Hentinen. } \\
2001^{67}\end{array}$ & $\begin{array}{l}\text { Cross-sectional mail } \\
\text { survey }\end{array}$ & $\begin{array}{l}213 \text { people with insulin- } \\
\text { treated diabetes aged } 17-65 \\
\text { years who visited health } \\
\text { centre or hospital ( } 76 \% \\
\text { response rate) }\end{array}$ & $\begin{array}{l}\text { Adherence to self-care according to } \\
\text { prescribed health regimen (S) }\end{array}$ & $\begin{array}{l}84 \% \text { of respondents accomplished daily insulin injections as } \\
\text { scheduled, while a further } 15 \% \text { accomplished near daily insulin } \\
\text { injections. Respondents were less adherent to urine testing, exercise } \\
\text { and dietary recommendations }\end{array}$ \\
\hline Kyngäs. $2001^{62}$ & $\begin{array}{l}\text { Cross-sectional } \\
\text { postal survey using } \\
\text { health register as a } \\
\text { sampling frame }\end{array}$ & $\begin{array}{l}1200 \text { children and } \\
\text { adolescents with epilepsy, } \\
\text { juvenile rheumatoid arthritis, } \\
\text { insulin-dependent diabetes } \\
\text { mellitus and asthma }\end{array}$ & $\begin{array}{l}\text { Compliance (including medication } \\
\text { compliance) coded as a } \\
\text { dichotomous variable (compliant } \\
\text { versus non-compliant) }\end{array}$ & $\begin{array}{l}\text { Support from nurses OR } 7.28(95 \% \mathrm{Cl} 3.95-13.42) \text {, energy and } \\
\text { willpower OR } 6.69(95 \% \mathrm{Cl} 3.91-11.46) \text { and good motivation OR } \\
5.28(95 \% \mathrm{Cl} 3.02-9.22) \text { were the strongest predictors of compliance }\end{array}$ \\
\hline
\end{tabular}




\begin{tabular}{|c|c|c|c|c|}
\hline $\begin{array}{l}\text { Author, date and } \\
\text { reference number }\end{array}$ & $\begin{array}{c}\text { Study design } \\
\text { and/or data source }\end{array}$ & Study sample & Relevant outcome measure(s) & Main findings \\
\hline Kyngäs. $2001^{56}$ & $\begin{array}{l}\text { Cross-sectional } \\
\text { postal survey using } \\
\text { health register as a } \\
\text { sampling frame }\end{array}$ & $\begin{array}{l}300 \text { children and } \\
\text { adolescents with epilepsy } \\
\text { aged } 13-17 \text { years ( } 77 \% \\
\text { response rate) }\end{array}$ & $\begin{array}{l}\text { Compliance (including medication } \\
\text { compliance) coded as a } \\
\text { dichotomous variable (compliant } \\
\text { versus non-compliant) }\end{array}$ & $\begin{array}{l}\text { Support from physicians OR } 10.56(95 \% \mathrm{Cl} 2.06-15.22) \text {, support } \\
\text { from parents OR } 10.47(95 \% \mathrm{Cl} 2.19-14.77) \text { and motivation OR } 9.77 \\
(95 \% \mathrm{Cl} 2.47-13.86) \text { were the strongest predictors of compliance }\end{array}$ \\
\hline Kyngäs. $2000^{57}$ & $\begin{array}{l}\text { Cross-sectional } \\
\text { postal survey using } \\
\text { health register as a } \\
\text { sampling frame }\end{array}$ & $\begin{array}{l}300 \text { children and } \\
\text { adolescents with epilepsy } \\
\text { aged } 13-17 \text { years }(77 \% \\
\text { response rate) }\end{array}$ & $\begin{array}{l}\text { Compliance with health regimens } \\
\text { (including medication compliance). } \\
\text { Compliance divided into } 3 \\
\text { categories; good, satisfactory and } \\
\text { poor }\end{array}$ & $\begin{array}{l}37 \% \text { categorised as having good medication compliance, and } 31 \% \\
\text { poor medication compliance }\end{array}$ \\
\hline Kyngäs. $2000^{65}$ & $\begin{array}{l}\text { Cross-sectional } \\
\text { postal survey using } \\
\text { health register as a } \\
\text { sampling frame }\end{array}$ & $\begin{array}{l}300 \text { children and } \\
\text { adolescents aged } 13-17 \\
\text { years with diabetes mellitus } \\
(97 \% \text { response rate })\end{array}$ & $\begin{array}{l}\text { Compliance with health regimens } \\
\text { (including medication compliance). } \\
\text { Compliance divided into } 3 \\
\text { categories; good, satisfactory and } \\
\text { poor }\end{array}$ & $\begin{array}{l}81 \% \text { of children or adolescents reported good compliance with } \\
\text { insulin treatment. } 48 \% \text { of children or adolescents reported their } \\
\text { treatment was planned together with physicians. } 49 \% \text { of children or } \\
\text { adolescents reported their treatment was planned together with } \\
\text { nurses }\end{array}$ \\
\hline Kyngäs. $2000^{69}$ & $\begin{array}{l}\text { Cross-sectional } \\
\text { postal survey using } \\
\text { health register as a } \\
\text { sampling frame }\end{array}$ & $\begin{array}{l}300 \text { children and } \\
\text { adolescents aged } 13-17 \\
\text { years with juvenile } \\
\text { rheumatoid arthritis ( } 91 \% \\
\text { response rate) }\end{array}$ & $\begin{array}{l}\text { Compliance (including medication } \\
\text { compliance) divided into } 3 \\
\text { categories; good, satisfactory and } \\
\text { poor }\end{array}$ & $\begin{array}{l}3 \% \text { categorised as having good medication compliance, } 52 \% \\
\text { satisfactory medication compliance and } 45 \% \text { poor medication } \\
\text { compliance }\end{array}$ \\
\hline
\end{tabular}

